\title{
Commitment of Journalistic Discourse in Construction of National Identity
}

\author{
Mihaela-Gabriela Păun \\ Secondary School No. 1, 26 Cireșului Street, Balș, Olt County, Romania \\ E-mail address: mihapau75@yahoo.com
}

\begin{abstract}
The study is a focused application on the imagology field. The thesis in whose direction it is argumented is the following: a) the concept of identity retrieved in psychology, sociology, philosophy; b) the vision of the Romanians about themselves sequential exposed in the pages of the magazine „Dilema Veche" ("Old Dilemma”) in the period September-October 2006. Recently appeared on the scientific scene, the concept of identity is an essential component of the social contemporary existence. Romanian masters discover with sadness that in 2006 elements of cultural and identity, tradition are still imported and that's why, badly understanding democracy and liberty, Romanians allow themselves anything: gregarious spirit, colloquial talking, violence, brutish, arbitrariness. According to N. Berdiaev the concept of liberty implies respects the other's liberty, namely: we are free as long as personal liberty doesn't defy the other's right to liberty. The chaos and haste are the two constants that control the Romanians amplifying stress, abridging them the deepness of things. It is to be remarked also the superficiality and indifferent attitude towards the people and rejecting the values to the new generation which, although wanting to be free, still remains stuck into libertinism.
\end{abstract}

Keywords: imagology; concept of identity; national identity; Romanian journalism

\section{INTRODUCTION}

The concept of identity appeared on the ladder of history relatively recent, having various forms: cultural, national, social identity etc. (Wachman, 1994; Wodak, 2009).

The identity in the psychology field, ,depends directly a series of elements as self-image (the mental image of a person about itself), self-esteem and individuality. An important part of the identity in the psychological sense is the gender identity, determining significantly the way in which a person sees itself as person and social being. In the cognitive psychology, the term of identity refers to ,the capacity of introspection of the person and self-conscience" (Leary \& Tangney, 2003).

Erik Erikson „was the first psychologist who takes interest explicitly in the problem of identity. The Eriksonian scheme bases on a distinction between the identity of the self (the psychological sense of the continuity), personal identity (personal idiosyncrasy which discern a person from its fellow) and social and cultural identity (assembly of social roles a person can play), (Erikson, 1972). James Marcia imposes at the end of the $20^{\text {th }}$ century the Neo-Eriksonian paradigm of the status of identity. It focuses on the concepts of exploration and assuming. The identity sense of every person is determined by the explorations and assuming which the person makes in what concerns certain personal features, constitutes the central idea of this paradigm. 
That's why most of the research on the level towards a person accomplish certain explorations and the level of his assuming. The anthropologists Cohen and Bray „,moved the center of interest of the analytic study from ,identity' to the limits used in the purpose of realizing the identification" (Cohen, 1998; Bray, 2004).

The philosophic discourse upon identity starts with Rene Descartes. Appeared in „Discourse about method", in 1637, the principle of „cogito ergo sum” determined many people to ask themselves what is this self and if we can define this self starting from a doubt. Hegel rejects the cartesian philosophy, saying that we are always conscious and that's why there is no doubt. In his famous dialectic master-slave, Hegel is trying to show that the spirit/mind (Geist) becomes conscience only when it meets another spirit/mind. Nietzsche, influenced by Hegel, proposes "Glad Science" the rejecting of the "atomism of the soul". He supposed that the soul is an interaction of forces something in a continuous change, far away from the immortal soul affirmed by Descartes and Christian tradition. From many points of view, the nietzschean "construction of the soul" is like the social and modern constructivism. Martin Heidegger also reflected upon the problem of identity. For him, only the confrontation with death offers the people the possibility to form an identity (Vlăduţescu, 2004; Vlăduţescu, 2009). This allows the people to choose between the senses socially built in their world and combine a finite identity from the infinity of the senses. In the conception of Heidegger, death is eliminated through ambiguity, although most people can't get rid of "them"- an identity socially built of "the way in which a person must be".

Paul Ricoeur introduced the distinction between "ipse" identity (himself/herself/who am I?) and "idem" identity (the same, a perspective of a third one who objectifies the identity) (Ricoeur, 1995) (also, Borowski, 2013a; Borowski, 2013b).

In the analysis of the phenomena in various fields and domains of research, the lens of "identity" is massively used and the problem of identity and construction of identity is an essential component of the social and contemporaneous existence. In this context we can say that: the idea according to which a person has a unique identity developed relatively recent in history (Vlăduţescu \& Ciupercă, 2013).

In the opinion of Herminia Ibarra "the centrality of the problem of identity in the social existence of our days is accentuated by the changes or transformations of identity. These can be produced at different levels of the social life, from the radical changes of the carrier to transformation of identity of genre and mutations of national identity" (Ibarra, 2003).

\section{IDENTITY ELEMENTS}

In this framework, we desire to realize a radiography of our national identity as it is shown in the pages of the magazine "Dilema Veche", in the period September-December 2006. In the conception of Sever Voinescu, Romanians suffer from a crisis of identity:" we don't know even us yet; we are looking for ourselves....woke up from a socio-political space into another...we are the ones who lived their adolescence under communism ...we are not aware of what is going on around us. We recreate our identity with cultural elements from abroad. We have been wandering for sixteen years in ambiguous roads, among beings which recompose periodically like in a sinister logo, laying in a sort of hopeless equivoque" (Sever Voinescu, Dilema Veche, 2006). At the level of the year 2006, we can say that in Romania it is made commercial use of the past, a trend which is still in vogue (Dima \& Vlăduțescu, 2012c; Vlăduţescu, 2013a). 
For Romanians, time has a different meaning - the forgetness stores its floating. Robert Turcescu surprises in his article: "Pe contrasens" ("The opposite") this convulsion in the hill of humankind: "In the race with the present, everybody runs to be a winner. That's why, the cars drive away honking among the curses addressed to the late ones. The newspapers salesman situated between their cars- a doll with the key in the back, as the boy transformed into a windscreen wiper. The whole landscape is dominated by automatic gestures of the "robots" planted in the crossroads: take the newspaper, give me the newspaper, spray the windscreen, wipe the windscreen. At school, the sleepy kids are debarked from the cars, running, while the bigger students "relax" with the last cigarette before going to classes" (Turcescu, 2006).

The whole world obeys the hurry! In a very short day you must divide yourself between job, TV and family (Dima \& Vlăduțescu, 2012a; Dima \& Vlăduțescu, 2012b). In this way, the girlfriends are "caressed while they are washing the dishes and the favorite team is on TV. The movements are mechanical and in a rush. There is an affinity with the boy, wiper of the windscreen and the man who kisses his wife. Everything is in a hurry: days, years, lovers, ages. We are hurried guests in our own existence....under the sign of illusion, always running for tomorrow, living with the illusion of having a full life. Suddenly a huge emptiness.....the boy is coming to wipe the windscreen of an unclear life from which we haven't seen almost anything" (Turcescu, 2006).

In what concerns politeness-the transition one: people, releasing from the pressure of fear after 1989 and badly understanding democracy and liberty, allow themselves everything: the gregarious spirit, violence, colloquial talking, brutish and arbitrariness (Vlăduţescu, 2011a; Vlăduţescu, 2013b). That's why many good manners today seem useless caprices. For example the kissing of the hand: "In the old times, the kissing of the hands between lovers was instead of kissing on the mouth. In this gesture there was respect and intimacy, a desire that kept the appearance of a neutral touch" Nicolae Iorga remarks in the article "De ce scade politetea in sondaje?" ("Why politeness falls in polls") (Iuga, 2006). In the conception of the recent-man, this gesture, in other times a noble one, is regarded as something zany- an unsanitary gesture, useless and ridiculous, just like the perukes of the old barons (Nora Iuga, 2006). In what concerns politeness we should take into consideration the opinion of the same lady:" the politeness is pushed to the edge, mocked at and compromised as an old coat, eaten by moths, or like the historical parties which in some people's vision "lived their life and ate their maze". Is liberty the main enemy of politeness?

If I am free, I do whatever I wanna do!" (Nora Iuga, 2006). But what about offering your seat in a bus? If this practice, once was admired, nowadays the "old men" receive the recommendation to stay home and not to disturb the people walking around" (Nora Iuga, 2006). "Why should I help that gimpy get off the bus pretending to be kind, when what I really want is to help the girl whose belly button attracts me for more than five stations? - who knows some fun can come out of this situation?! Everything is to be understood in this world! (Nora Iuga, 2006). In the year 2006, "curses appear as revenge, because is 'cool', and this behavior is considered to be "cool". Without having a real handicap, the youngsters have the revendications of a pregnant woman, invalid and old people, sitting on the seats of the bus "with their small headphones in their ears, eating a chocolate bar, chattering their cheeks, as a 'modellino': Well, yes it is reserved for me...because I am pregnant... and the kid breaks into a wild laugh and then he turns his head scornful, to the window (Dilema Veche, 2006).

In what concerns Romanians and their passions, it can be remarked, in the mentioned period, that the wellness, for Romania, means: the history of a football match won by a certain team, interrupted by some short bad news. In this context, the country seems to resemble to a human marmalade- which discovers curiously the friendship on a blog. This unhealthy world 
wants to be appropriate to our needs of affirmation. Here, everything is under the sign of simplicity: the distances between people disappear, the gestures, language bend over the shortcuts of the new way of life. Romanians become the fans of the simplified language, at the level of an sms: pls, tks, : ) )...what you cannot solve with the language you solve with physical touch...With naivety, our fellows, post intimate confessions and trust their "friends from the internet "from the second conversation" (Dilema Veche, 2006). "The change of regime, from December 1989, brought a series of words which rapidly turned into clichés, automatisms of speaking and thinking, which mirrored in the new social-political realities some of these stereotypical formulas had a short existence, in certain historical moments( for instance the word "Golan" - guttersnipe, initial having a positive connotation in the context of the manifestations from Piata Universitatii, became, through semantic extension, a synonym for "anticommunist fighter", to emanate, emanation- a product of revolution, Dalmatian- a person with a spotted biography because of his behavior from the communist period ) and others survived until today and configured the so called "wooden language "of the Romanian transition”(A. Stoichitoiu Ichim, 2006) (also, Vlăduţescu, 2011b; Vlăduţescu, 2013c).

Above all these "we are colloquial without being cordial and we practice the closeness, which manages to chase away. We participate at dialogues blaming the initiator of the theme, showing suspicion, hostility and curses, adhering at categories and subcategories of people and finally all ends. In the morning we begin again like brothers" (Dilema Veche, 2006). Another kind of brotherhood is the "televisional weddings". Romanians prefer in the happiest moment of the beginning of the road in two "manelists who get puffed up, godmothers big as the barrel from the cellar from Cotnari. The televisional weddings are full of naiveties and mobish people, greed and circus" (Dilema Veche, 2006). Although Silviu Brucan said that "our mind will stay were our interests are, the mind of the happy Romanians wanders after Swarovsky crystals, tulle and flounces. Remaining outside the sphere of popular love, we must mention that the vocabulary of love lacks sweet words, sensual and delicate expressions. That's why it is said that " the man and the woman had "interflow", "binding", he "fecundated" her (Dilema Veche, 2006).

We should point out that "Romanians are large-hearted, beautiful, passional and masters of the language. The country itself is a real treasure of extraordinary landscapes, mysterious mountains, deep forests and old villages" (Codrescu, 2006); people have a vital force, which sacredly keep the inheritance received from their ancestors and at their turn, they do their duty and transmit it forward (Vlăduţescu, 2012; Freytag, 2013; Tittenbrun, 2013).

Romanians can be proud of their women, handsome, with hollow eyes, a little sad, having calm way of talking and being respectable. As about the men... most of them have a round face, big backhead and bellies at thirty years, driving expensive cars, Logan and Volkswagen. The feminine ideal from their perspective is: competent masseurs, excellent cooks, and not to yell...better said... dumb...

A special visit card is the Romanian kitchen, with various menus and from specific areas. Vegan or not, special bread, aubergine salad, "sarmaua" (cabbage with meat, as the French call it when they come to change experience) but especially "mititeii" are a delicacy from the point of view of the strangers who come into our houses.

Romanians can be proud of intelligence: in 1900 at an exhibition in Paris having the specific of identity and reuniting countries from all over the world; the Romanian band, leaded by Barbu Lautaru astonished the people who attended the exhibition when the electricity interrupted. They continued to sing and delight. The same Barbu Lautaru impressed Franz Liszt who had come in tournament in our country and who, fascinated by the popular, Romanian music wrote a Romanian Rhapsody which had the opening at the Ateneul Roman on 17 
December 1931. Remaining in the sphere of the music we should remember George Enescu. Then, Eminescu in literature, Brancusi in art and the greatest Romanian inventors: Vlaicu, Coanda (whose principle lays in the vertical lifting) etc.

Anyway, at the end of the year 2006, Romania couldn't find itself. The masters of the pen were in a big identity crisis. Memorable in this sense is the confession of Octavian paler who found himself in a big dilemma, in the same year: "Which Romania is this all about? Romania of Gigi Becali? Romania of Basescu, Gioana or C. V. Tudor? Romania that I see on TV? Romania, that I see on the street? Romania keeps on "files"? Romania which discusses on TV the lists with the Great Romanians? Romania which swears that it doesn't have time to see how the leaves are leaning in the trees or how the evening is full of metaphysics, because it is busy to talk on the mobile phone and when they get into the bus or get off the bus or cross the street? Romania where the grossness is prosperous? Romania which discovered - the new hideous form of enduring quietly the history? Romania which hates the old people? Romania which oscillates between curses and slavishness? Romania of the sordid lands? Romania, crazy for manele? Romania which managed 16 years ago to organize disappointments where democracy and liberty look ugly? Romania, capable of putting a grill in every part of Golgota? Romania where probably even in Hell will look with antipathy towards the pessimists? If this is RomaniaI answered- I don't hesitate to say I don't like it! I am patriot as long as I don't open the TV and I don't go on the street. I love a Romania which never existed and perhaps never will. From a simple reason: I also had a mother and a father" (Octavian Paler, Dilema Veche, 2006).

\section{CONCLUSION}

The period of communism destroyed the self-esteem of the Romanians, and this thing is visible in the Romanian journalism. The study of imagology realized in the period SeptemberOctober 2006, took into account Dilema Veche, being convincing in this respect. Still being in a period of transition, Romanians are still enchanted by a new way of communication, dominated by a "wooden" language sometimes, or flavored with salt and pepper, language which can be enclosed in the suburban category. The chaos and hurry are the two constants which control the Romanians amplifying stress, disposing them of the profoundness of the things. It is to be remarked also, the superficiality, the indifferent attitude towards their fellows and rejecting the values by the new generation who, although wanting to be free, still remains stuck into libertinism.

\section{References}

[1] Borowski Andrzej (a), International Letters of Social and Humanistic Sciences 1 (2013) 19-27.

[2] Borowski Andrzej (b), International Letters of Social and Humanistic Sciences 4 (2013) 70-74.

[3] Bray Z. (2004). Living Boundaries: Frontiers and Identity in the Basque Country. Brussels: Presses interuniversitaires européenes - Peter Lang.

[4] Codrescu Andrei, Dilema Veche 141 (2006). 
[5] Cohen A. (1998). Boundaries and Boundary-Consciousness: Politicising Cultural Identity. In M. Anderson \& E. Bort (Eds.), The Frontiers of Europe. London: Printer Press.

[6] Dilema Veche (2006). September-December. Available: http://supravietuitor.wordpress. com/2009/10/31/dragii-mei-compatrioti-romani-eu-nu-mai-emigrez-din-romania.

[7] Dima I. C., Vlăduțescu Ștefan (2012a). Persuasion Elements Used in Logistical Negotiation: Persuasive Logistical Negotiation. Saarbrucken: LAP Lambert.

[8] Dima I. C., Vlăduţescu Ştefan (b), European Journal of Business and Social Sciences 6(1) (2012) 27-33.

[9] Dima I. C., Vlăduţescu, Ştefan (c), International Journal of Management Sciences and Business Research 1(9) (2012) 1-11.

[10] Erikson Erik (1972). Childhood and Society. Harmondsworth: Penguin Books Ltd..

[11] Freytag Stefan, International Letters of Social and Humanistic Sciences 10 (2013) 25-31.

[12] Ibarra, Herminia (2003). Working identity: unconventional strategies for reinventing your career Cambridge, MA: Harvard Business Press.

[13] Iuga, Nora. Dilema Veche, 149 (2006) Available:

http://dilemaveche.ro/sectiune/dileme-line/articol/ce-scade-politetea-sondaje-0.

[14] Leary M. R., Tangney J. P. (Eds.). (2003). Handbook of self and identity. New York: Guilford Press.

[15] Nietzsche F. (2013). Ştiinţa voioasă. București: Editura Humanitas.

[16] Nowicka-Scowron M., Dima I. C., Vlăduțescu Ştefan, International Journal of Management Sciences and Business Research 1(8) (2012) 27-35.

[17] Paler Octavian. Dilema Veche 139 (2006). Available: http://www.gds.ro/Opinii/2006-09-11/\%E2\%80\%9EDilema+Veche\%E2\%80\%9C+ma+pus+in+dilema.

[18] Ricoeur Paul (1995). Oneself as Another. Chicago: University of Chicago Press.

[19] Stoichiţoiu Ichim A. (2006). Creativitate lexicală în româna actuală Bucureşti: Editura Universităţii din Bucureşti.

[20] Tittenbrun Jacek, International Letters of Social and Humanistic Sciences 11 (2013) 10-34.

[21] Turcescu Robert. Dilema Veche 180 (2006). Available: http://bobyc86.blogspot.ro/2006_12_01_archive.

[22] Vlăduţescu Ştefan (2004). Comunicologie şi Mesagologie. Craiova: Editura Sitech.

[23] Vlăduțescu Ştefan (2009). Concepte şi noţiuni de Comunicare şi Teoria mesajului. Craiova: Editura Sitech.

[24] Vlăduțescu Ştefan (a), Revista de psihologie 57(3) (2011) 201-213.

[25] Vlăduțescu Ştefan (b), Revista de psihologie 57(4) (2011) 359-366. 
[26] Vlăduțescu Ştefan, Revista de psihologie a Academiei Române 58(1) (2012) 57-64.

[27] Vlăduțescu Ștefan (a), Jokull Journal 63(8) (2013) 186-197.

[28] Vlăduțescu Ștefan (b), Jokull Journal 63(9) (2013) 301-318.

[29] Vlăduțescu Ștefan (c), Revista de psihologie 59(3) (2013) 254-263.

[30] Vlăduțescu Ștefan, Ciupercă Ella Magdalena (2013). The Next Level of Communication: Social Networks. Aachen: Shaker Verlag.

[31] Wachman A. (1994). Taiwan-: National Identity and Democratization. ME Sharpe.

[32] Wodak R. (2009). The discursive construction of national identity. Edinburgh University Press. 